\title{
SIMULATED IMPACTS OF CLIMATE CHANGE ON WATER USE AND YIELD OF IRRIGATED SUGARCANE IN SOUTH AFRICA
}

\author{
JONES M R ${ }^{1}$, SINGELS A ${ }^{1,2}$ and RUANE, A $C^{3}$ \\ ${ }^{1}$ South African Sugarcane Research Institute, Private Bag X02, Mount Edgecombe, 4300, South Africa; Tel: \\ +27 31508 7441. Email: matthew.jones@sugar.org.za. (Corresponding author) \\ ${ }^{2}$ Department of Plant Production and Soil Science, University of Pretoria, Pretoria, South Africa; Tel: +2731 \\ 508 7446; Email: abraham.singels@sugar.org.za \\ ${ }^{3}$ Climate Impacts Group, National Aeronautics and Space Administration Goddard Institute for Space Studies, \\ 2880 Broadway, New York, NY 10025, USA; Tel: +001 212-678-5640; Email: alexander.c.ruane@nasa.gov
}

\begin{abstract}
Reliable predictions of climate change impacts on water use, irrigation requirements and yields of irrigated sugarcane in South Africa (a water-scarce country) are necessary to plan adaptation strategies. Although previous work has been done in this regard, methodologies and results vary considerably. The objectives were (1) to estimate likely impacts of climate change on sugarcane yields, water use and irrigation demand at three irrigated sugarcane production sites in South Africa (Malelane, Pongola and La Mercy) for current (1980-2010) and future (2070-2100) climate scenarios, using an approach based on the Agricultural Model Intercomparison and Improvement Project (AgMIP) protocols; and (2) to assess the suitability of this methodology for investigating climate change impacts on sugarcane production.
\end{abstract}


Future climate datasets were generated using the Delta downscaling method and three Global Circulation Models (GCMs) assuming atmospheric $\mathrm{CO}_{2}$ concentration $\left[\mathrm{CO}_{2}\right]$ of $734 \mathrm{ppm}(\mathrm{A} 2$ emissions scenario). Yield and water use were simulated using the DSSAT-Canegro v4.5 model.

Irrigated cane yields are expected to increase at all three sites (between 11 and 14\%), primarily due to increased interception of radiation as a result of accelerated canopy development. Evapotranspiration and irrigation requirements increased by $11 \%$ due to increased canopy cover and evaporative demand. Sucrose yields are expected to decline because of increased consumption of photo-assimilate for structural growth and maintenance respiration. Crop responses in canopy development and yield formation differed markedly between the crop cycles investigated.

Possible agronomic implications of these results include reduced weed control costs due to shortened periods of partial canopy, a need for improved efficiency of irrigation to counter increased demands, and adjustments to ripening and harvest practices to counter decreased cane quality and optimise productivity.

Although the Delta climate data downscaling method is considered robust, accurate and easily-understood, it does not change the future number of rain-days per month. The impacts of this and other climate data simplifications ought to be explored in future work. Shortcomings of the DSSAT-Canegro model include the simulated responses of phenological development, photosynthesis and respiration processes to high temperatures, and the disconnect between simulated biomass accumulation and expansive growth. Proposed methodology refinements should improve the reliability of predicted climate change impacts on sugarcane yield.

Keywords: climate change, model, cane yield, irrigation requirement, water use. 


\section{Highlights}

- Climate change is likely to increase sugarcane yields in South Africa by $11 \%$

- Climate change is likely to reduce cane quality and sucrose yields

- Sugarcane irrigation requirement is projected to increase by $11 \%$

- Yield and irrigation changes are driven by accelerated canopy development

- Adaptations could include more efficient irrigation technology, reduced harvest age

- DSSAT-Canegro canopy development responses to climate change require improvement

\section{INTRODUCTION}

\subsection{Background}

South Africa is a water-scarce country. Sugarcane (complex hybrid of Saccharum spp.) is grown on a 12-month cycle under full irrigation in the northern KwaZulu-Natal and Mpumalanga regions of the South African sugar industry, where annual average rainfall is typically approximately 700 and $500 \mathrm{~mm}$ respectively, while atmospheric demand for water in these regions ranges from 1600 to $1800 \mathrm{~mm} / \mathrm{annum}$ (Inman-Bamber, 1995). Supplementary irrigation is used in parts of the Zululand, North Coast and Midlands regions as well, where annual rainfall is generally just sufficient to sustain economically-viable rainfed sugarcane production (800-1200 mm/annum) on harvest cycles ranging from 12 to 24 months. Approximately $22 \%$ by land area (77 000 ha) of the South African sugar industry is irrigated, but irrigated regions account for approximately $35 \%$ of average total annual sugarcane production ( 7 million tons of cane). The economic sustainability of the irrigated sugarcane sector is of vital importance to the continued success of the South African sugar 
industry. Reliable predictions of climate change impacts on water use, irrigation requirements and yields of irrigated sugarcane are of critical importance for planning adaptation strategies.

Knox et al. (2010) used the DSSAT-Canegro v3.1 (Jones et al., 2003) model to predict that expected climate change in the 2050s could increase sugarcane irrigation requirements by $21 \%$, and sucrose yields by about $15 \%$, in Swaziland. Rainfed sugarcane yield increases of 15 to 40 t/ha to intermediate future (2050s) climate were also reported by Schulze and Kunz (2010) for South Africa. Marin et al. (2012) reported a 24\% increase in rainfed sugarcane yields, and a 34\% increase in water use efficiency in south-eastern Brazil (2100s). Singels et al. (2013) reported increases in future (2100s) crop water use of 1 to $8 \%$, and cane yield increases of 4 to $20 \%$ for sites in SA, Australia and Brazil (2100s), while sucrose yield responses varied widely (between $-33 \%$ and $+13 \%$ ). Schulze and Kunz (2010) reported likely increases in irrigation demand of $10-20 \%$ on average across the country for the end-ofcentury time period, although with considerable spatial variation: some hinterland catchments in the KwaZulu-Natal province in particular indicating either no change or reduced irrigation demand in the order of $0-10 \%$, because of increased projected rainfall. Although these studies give a general indication of likely yield increases and probable increases in water use, there is much heterogeneity in the climate and crop models used as well as the assumptions made (such as whether or not effects of elevated atmospheric carbon dioxide content on the plant are considered). Impacts also vary as a result of soil and climate differences. In many cases single climate models are used, limiting insights into the uncertainty or likelihood of projected climate changes. These factors make it difficult to draw robust conclusions regarding the impacts of climate change on the irrigated sugarcane in South Africa, in terms of yield and irrigation water demand. 
A deeper understanding of the impacts of climate change on irrigated sugarcane production in South Africa will facilitate the exploration of possible adaptation strategies for minimising the negative impacts, and maximising the positive aspects, of climate change. Easterling (2011) reports on technological innovation and 'human ingenuity' as key tools in a 'toolkit' for climate change adaptation of socio-agroecological systems. Technological innovation includes plant breeding and genetic diversification, and the conservation of energy, water and soil; the human ingenuity category includes changes to agronomic practices. Several authors have suggested adaptation strategies for irrigated sugarcane production that fall into these categories. Park et al. (2010) reported on adaptation of the Australian sugar industry to climate change. Suggested technological and management changes include implementation of improved irrigation water delivery technologies such as drip irrigation, land grading, use of residue layers and irrigation application scheduling; breeding of improved sugarcane varieties with traits for greater drought resistance, water use efficiency and tolerance of high temperatures; and the introduction of improved and more flexible agronomic management strategies including adjustments of crop start dates, choice of varieties, retention of crop residues and more careful management of nutrients and pest and diseases. Nkomo and van der Zaag (2004) for Swaziland and Chandiposha (2013) for Zimbabwe recommend adoption of micro- and drip irrigation, with the latter also recommending use of irrigation scheduling and expansion of irrigation and drainage infrastructure. Chandiposha (2013) speculated that genetic adaptation of varieties (by conventional breeding or genetic modification) to be tolerant of drought, water-logging and salinity, and to have 'self-trashing' traits (i.e. the tendency to detach dead leaves), would be appropriate for future sugarcane production in Zimbabwe. Schulze and Kunz (2010) suggest that age at harvest could be decreased by 3-5 months in the South African sugar industry in the intermediate and more distant future, and also highlight the probable need to breed more heat-tolerant varieties of sugarcane. 
The Agricultural Model Intercomparison and Improvement Project (AgMIP, Rosenzweig et $a l ., 2013)$ aims to characterise the impacts of climate change on food production and risk of hunger, globally, and for all crops. AgMIP has developed set of protocols (Rosenzweig et al., 2013) for conducting regional climate change impact assessments that integrate sets (ensembles) of climate, crop and economic simulation models, at different time-scales and under different emissions scenarios. One of the future climate projection downscaling methods described in these protocols is the simple Delta approach, which imposes changes to rainfall amounts and temperature at a monthly resolution. The model ensemble approach allows for a better appreciation of the uncertainty associated with projections.

\subsection{Objectives}

The objectives of the study were to estimate likely impacts of climate change on sugarcane yields, water use and irrigation demand at three irrigated sugarcane production sites in South Africa, using the DSSAT-Canegro sugarcane model and the Delta climate projection downscaling methodology from the AgMIP protocols; and to assess the strengths and weaknesses of the methodology for simulating climate change impacts on sugarcane.

\section{METHODOLOGY}

Irrigated and rainfed sugarcane production was simulated at three sites in South Africa (Figure 1) for a 30-year historical baseline period and a future 30-year period using climate projections from three climate models. Model outputs were then analysed and summarised in order to address the objectives of the study. 


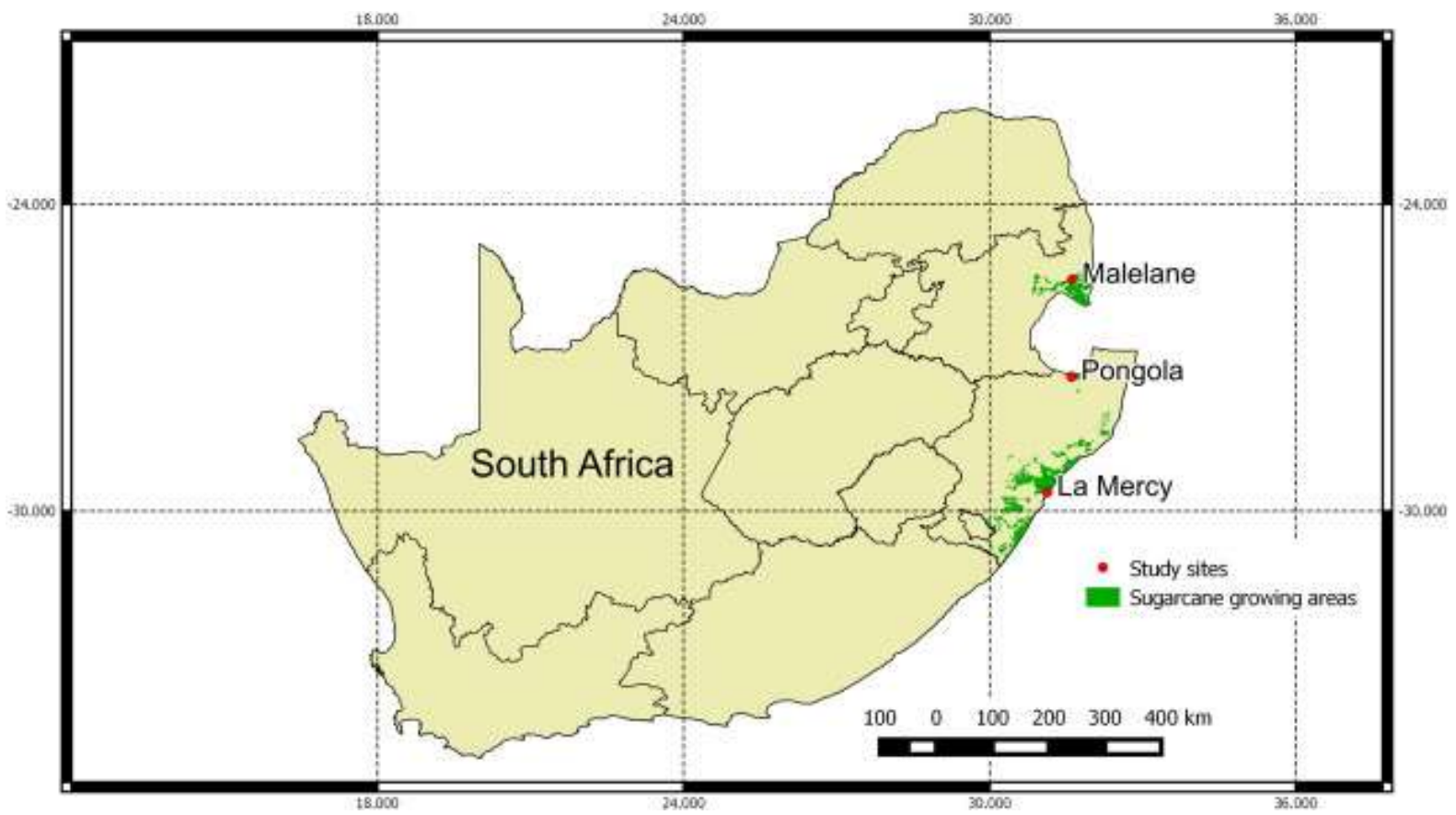

Figure 1. Map showing study sites and sugarcane-growing areas in South Africa.

\subsection{Crop model description}

Simulations were conducted using the DSSAT-Canegro v4.5 model (Singels et al., 2008), modified to be sensitive to atmospheric $\mathrm{CO}_{2}$ concentration $\left(\left[\mathrm{CO}_{2}\right]\right)$. The basic operation of the Canegro model is as follows: air temperature and soil moisture availability determine crop timing (germination and emergence, shoot and leaf appearance rates) and leaf and stalk growth rates; fractional interception of photosynthetically-active radiation is calculated from leaf area and drives gross photosynthesis $\left(P_{G}, \mathrm{t} / \mathrm{ha} / \mathrm{d}\right)$; daily net biomass accumulation is simulated as the difference between (1) gross photosynthesis, which is based on a temperature-dependent photosynthetically-active radiation conversion efficiency (i.e. radiation use efficiency (RUE)), and (2) the sum of growth respiration $(R g(\mathrm{t} / \mathrm{ha} / \mathrm{d})$ and temperature-dependent maintenance respiration (Singels et al., 2005); biomass is partitioned into roots, leaves, stalk non-sucrose and stalk sucrose according to air temperature and soil water availability (Inman-Bamber, 1991; Singels and Bezuidenhout, 2002). The DSSATCanegro v4.5 model was previously calibrated for sites in South Africa, Zimbabwe, Brazil, 
Australia and Thailand (Singels et al., 2010). Validation of the model for 16 crops at two sites in South Africa revealed a root mean squared error (RMSE) of $6.62 \mathrm{t} / \mathrm{ha}$ for stalk dry mass and 3.59 t/ha for sucrose mass (Jones, 2013). An earlier stand-alone version of the Canegro model, the predecessor of the DSSAT-Canegro v4.5 model, underwent robust validation using data from 19 treatments from diverse experiments conducted in South Africa, producing RMSEs of $5.5 \mathrm{t} / \mathrm{ha}$ for stalk dry mass and $2.6 \mathrm{t} / \mathrm{ha}$ for sucrose yield (Singels et al., 2002).

The DSSAT-Canegro v4.5 model was modified to be responsive to $\left[\mathrm{CO}_{2}\right]$ by reducing transpiration rates with increasing $\left[\mathrm{CO}_{2}\right]$ (as described by Singels et al., 2013). No direct effect on photosynthesis of $\left[\mathrm{CO}_{2}\right]$ was simulated. Vu et al. (2006), de Souza et al. (2008) and Allen et al. (2011) found increased photosynthesis rates at elevated $\left[\mathrm{CO}_{2}\right]$ in pot experiments, but improved crop water status through stomatal response may have contributed significantly to these observed responses. Vu and Allen (2009) found significant increases in leaf area and dry biomass to elevated [CO2] for single plants in pots, but no response in leaf level photosynthesis rate. Stokes and Inman-Bamber (2014) also found no significant effect on photosynthesis when crop water status was optimal.

\subsection{Site description, climate and model settings}

\subsubsection{Experimental sites}

Three sites in South Africa (SA) were selected for this study (Figure 1). These were: La Mercy (29³4'30" S, 31 ${ }^{\circ} 08^{\prime} 45^{\prime \prime}$ E (72 m a.s.1.)) on the KwaZulu-Natal (KZN) north coast, where supplementary irrigation is sometimes used, and represents a medium-potential cane

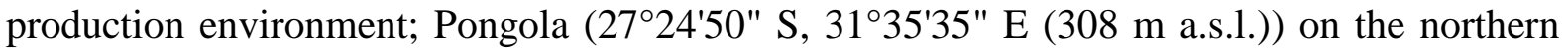
border of the KZN province, where sugarcane is mostly irrigated and represents a mediumhigh potential production environment; and Malelane $\left(25^{\circ} 28^{\prime} 36^{\prime \prime} \mathrm{S}, 31^{\circ} 32^{\prime} 08^{\prime \prime} \mathrm{E}\right.$ (301 m 


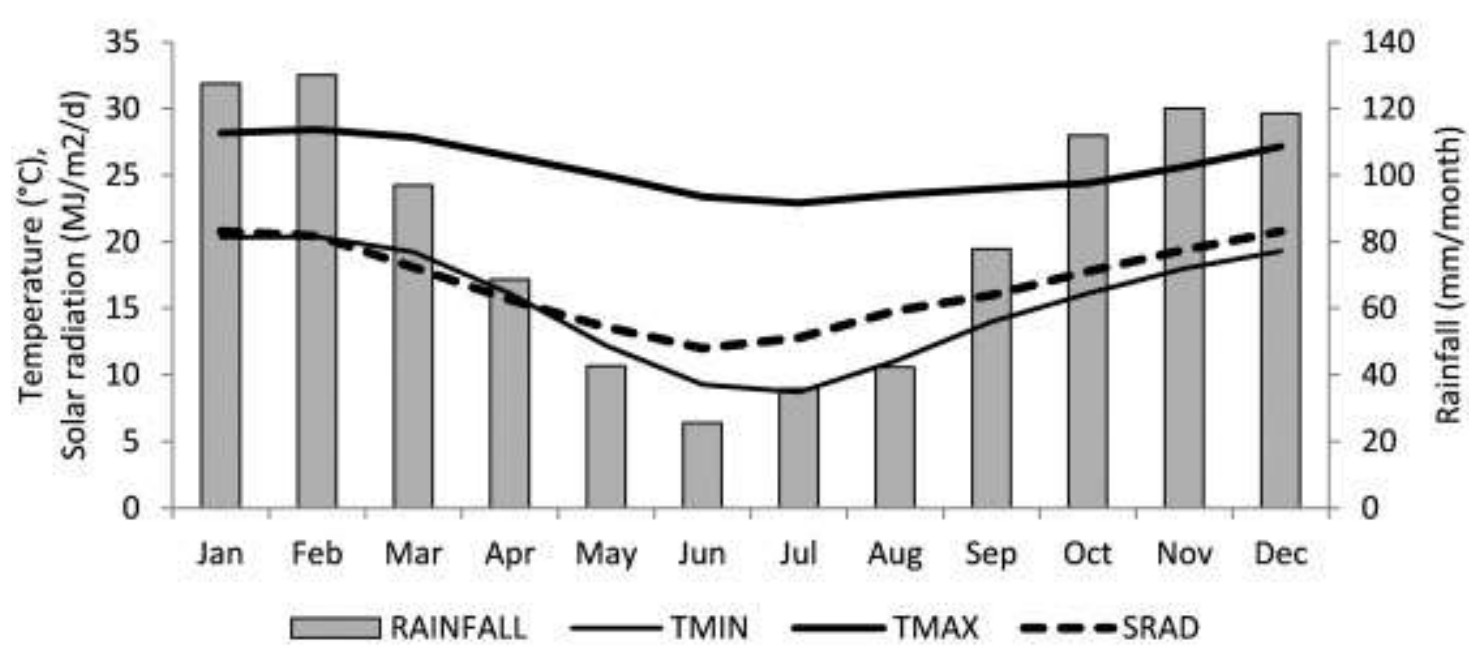

b

\section{Pongola}

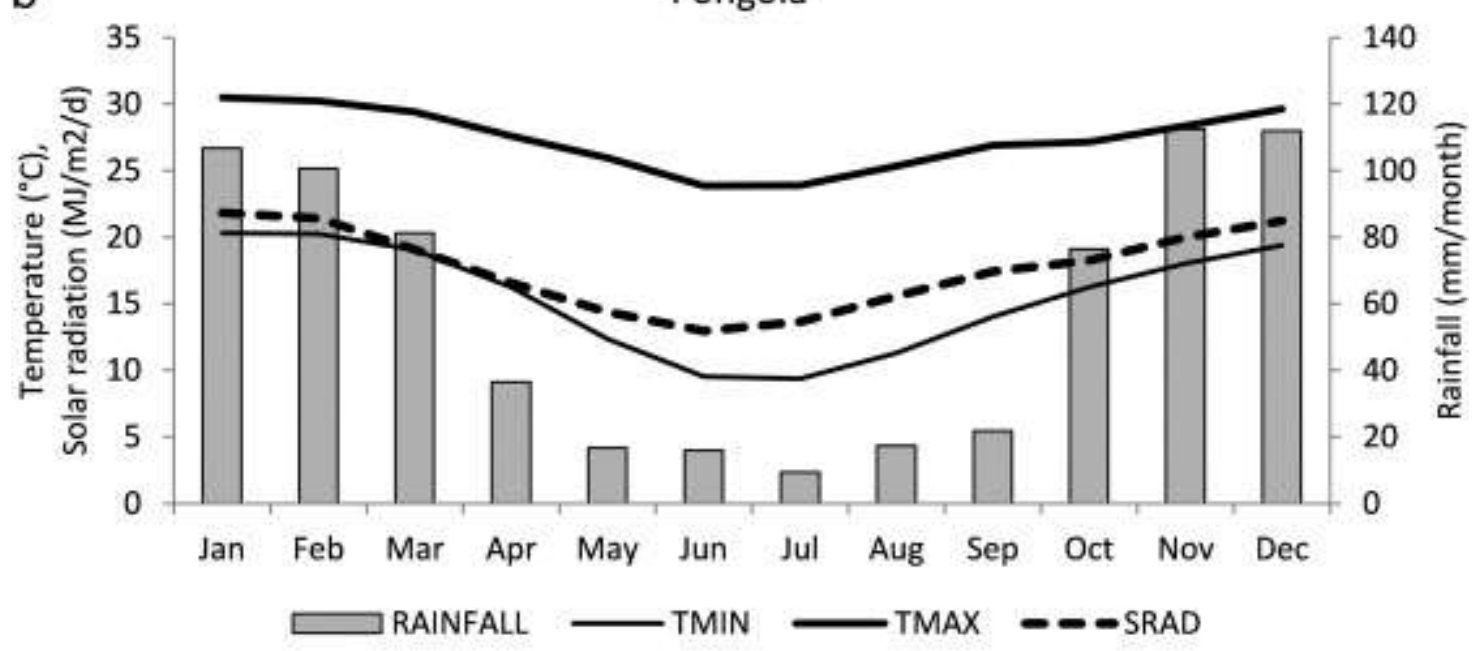

C Malelane

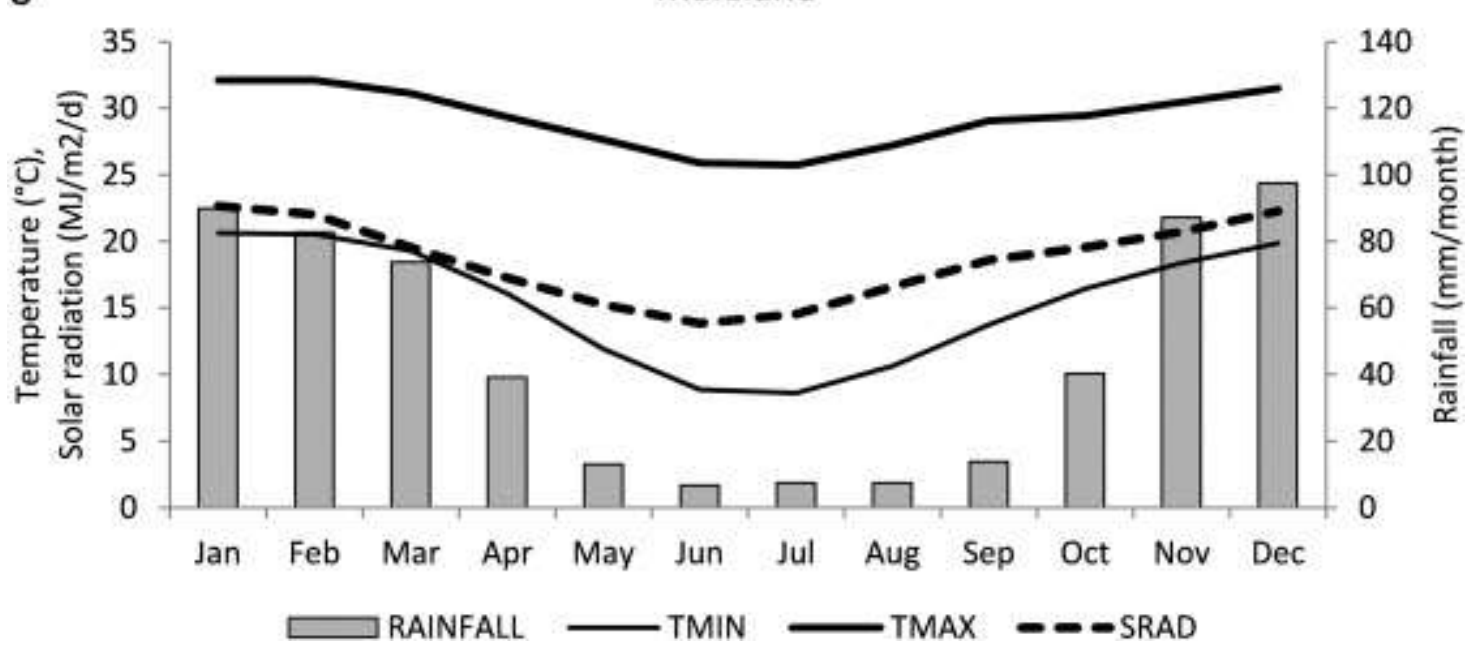

Figure 2. Monthly mean values for maximum daily air temperature $\left(\mathrm{TMAX},{ }^{\circ} \mathrm{C}\right)$, minimum daily air temperature (TMIN, $\left.{ }^{\circ} \mathrm{C}\right)$, daily incident solar radiation $\left(\mathrm{SRAD}, \mathrm{MJ} / \mathrm{m}^{2}\right)$ and mean monthly total rainfall (RAINFALL, mm), 1980-2010, at La Mercy, Pongola and Malelane. 
a.s.1.)), in the Mpumalanga province, where production is fully irrigated and is the highestpotential production region in the SA sugar industry. The key climatic descriptors for these sites are illustrated in Figure 2.

\subsubsection{Model settings}

Site details and cropping scenarios assumed for each site are summarised in Table 1. Overhead sprinkler irrigation was simulated, with $25 \mathrm{~mm}$ applied whenever the soil water content of the top $70 \mathrm{~cm}$ (i.e. maximum rooted depth) of the soil profile decreased below $60 \%$ of plant-available water-holding capacity. Cultivar parameters for NCo376 were used throughout. Although this cultivar is no longer grown widely under irrigation, it has been well researched, and its physiological traits are sufficiently similar to cultivars currently grown in irrigated areas for it to be a suitable cultivar for studies assessing climatic yield potentials. A single hypothetical soil profile (described in Table 2) was used in the simulations for all sites. A single soil facilitates meaningful comparison of climate change impacts between the different sites. The chosen soil is, in terms of water holding capacity, also representative of a large proportion of soils used for irrigated sugarcane production in South Africa. The soil water-holding capacity of the soil will have little effect on most of the results because water demand was adequately met in the simulations. Estimated irrigation demand, however, would depend on soil water-holding capacity. Both fully-irrigated and rainfed production were simulated at each of the sites. Ratoon crops were simulated in all cases. 
Table 1. Cropping details, baseline and future (average of three Global Circulation Model estimates) longterm annual rainfall, average maximum daily air temperature (TMAX), and average minimum daily air temperature (TMIN) for the three sites studied. Italicised values in parentheses show standard deviation of GCM-estimated average values.

\begin{tabular}{|c|c|c|c|c|c|c|}
\hline \multirow[t]{2}{*}{ Site detail } & \multicolumn{2}{|c|}{ La Mercy } & \multicolumn{2}{|c|}{ Pongola } & \multicolumn{2}{|c|}{ Malelane } \\
\hline & Baseline & Future & Baseline & Future & Baseline & Future \\
\hline $\begin{array}{l}\text { Coordinates and } \\
\text { altitude }\end{array}$ & $29^{\circ} 34^{\prime} 30^{\prime \prime}$ & ${ }^{\circ} 08 ' 45 " \mathrm{E}$ & $\begin{array}{r}27^{\circ} 24^{\prime} 50^{\prime \prime} \mathrm{S} \\
(30\end{array}$ & 35 '35" E & $\begin{array}{r}25^{\circ} 28 \\
31^{\circ} 32^{\prime} 08^{\prime \prime}\end{array}$ & $\begin{array}{l}\mathrm{S}, \\
301 \mathrm{~m})\end{array}$ \\
\hline Weather station & Tongaat- & fontein & Por & & Malelan & Ihlati \\
\hline Rainfall (mm) & 998 & $\begin{array}{r}1023 \\
(102.5)\end{array}$ & 707 & $\begin{array}{r}683 \\
(32.6)\end{array}$ & 559 & $\begin{array}{r}520 \\
(12.4)\end{array}$ \\
\hline $\operatorname{TMAX}\left({ }^{\circ} \mathrm{C}\right)$ & 25.6 & $\begin{array}{r}28.8 \\
(0.47)\end{array}$ & 27.4 & $\begin{array}{r}30.9 \\
(0.68)\end{array}$ & 29.3 & $\begin{array}{r}33.0 \\
(0.81)\end{array}$ \\
\hline TMIN $\left({ }^{\circ} \mathrm{C}\right)$ & 15.4 & $\begin{array}{r}18.6 \\
(0.47)\end{array}$ & 15.5 & $\begin{array}{r}19.0 \\
(0.68)\end{array}$ & 15.4 & $\begin{array}{r}19.1 \\
(0.81)\end{array}$ \\
\hline Crop start dates & $\begin{array}{r}1 \mathrm{Apr}, \\
1 \mathrm{Oct}\end{array}$ & $\begin{array}{r}1 \mathrm{Apr}, \\
1 \mathrm{Oct}\end{array}$ & $\begin{array}{l}1 \text { Apr, } \\
1 \text { Oct }\end{array}$ & $\begin{array}{l}1 \mathrm{Apr}, \\
1 \mathrm{Oct}\end{array}$ & $\begin{array}{r}1 \mathrm{Apr} \\
1 \mathrm{Oct}\end{array}$ & $\begin{array}{l}1 \mathrm{Apr}, \\
1 \mathrm{Oct}\end{array}$ \\
\hline $\begin{array}{l}\text { Age at harvest } \\
\text { (months) }\end{array}$ & 12 & 12 & 12 & 12 & 12 & 12 \\
\hline Row-spacing (m) & 1.2 & 1.2 & 1.4 & 1.4 & 1.4 & 1.4 \\
\hline
\end{tabular}

Table 2. Physical characteristics of the hypothetical soil used for crop model simulations.

\begin{tabular}{lr}
\hline \multicolumn{1}{c}{ Characteristic } & Value \\
\hline Albedo & 0.13 \\
Runoff curve number & 73 \\
Maximum rooting depth $(\mathrm{cm})$ & 70 \\
Bulk density $\left(\mathrm{g} / \mathrm{cm}^{3}\right)$ & 1.26 \\
Saturated hydraulic conductivity $(\mathrm{cm} / \mathrm{h})$ & 1.50 \\
Lower limit of plant-available soil water $\left(\mathrm{cm}^{3} / \mathrm{cm}^{3}\right)$ & 0.15 \\
Drained upper limit of plant-available soil water $\left(\mathrm{cm}^{3} / \mathrm{cm}^{3}\right)$ & 0.26 \\
Saturated limit of plant-available soil water $\left(\mathrm{cm}^{3} / \mathrm{cm}^{3}\right)$ & 0.35 \\
Plant-available soil water-holding capacity $(\mathrm{mm})$ & 77 \\
\hline
\end{tabular}

\subsection{Weather data}

\subsubsection{Historical weather data}

Daily weather observations for minimum and maximum air temperature (TMIN and TMAX respectively, $\left.{ }^{\circ} \mathrm{C}\right)$, incident solar radiation $\left(S R A D, \mathrm{MJ} \mathrm{m}^{-2}\right)$, rainfall $(R A I N F A L L, \mathrm{~mm})$, wind run $(W I N D, \mathrm{~km} / \mathrm{d})$ and maximum and minimum relative humidity (RHMIN and RHMAX respectively, \%), for 31 years (1980-2010), were assembled from weather station records for each site. Data gaps were patched using nearby stations or long-term mean values as 
necessary, and further corrections and gap-filling were performed using MERRA (Rienecker et al., 2011) reanalysis data. The historical dataset at each site is termed the 'baseline' weather data set. Thirty-one years was chosen as the weather data period as (a) this accommodated the World Meteorological Organisation's recommendation of 30 years as the minimum period required to characterise climate at a site (World Meteorological Organisation, 2007), while also accommodating 30 complete 12-month crops that are started one year and harvested the following year; and (b) longer periods presented practical difficulties in terms of locating reliable weather data. These data are summarised in Figure 2.

\subsubsection{Future climate data}

Future climate scenarios were derived from three GCMs from the Coupled Model Intercomparison Project Phase 3 (CMIP3, Meehl et al., 2007) for the end-of-century (20702100) A2 greenhouse gas emission scenario (Nakićenović et al., 2000) and $\left[\mathrm{CO}_{2}\right]$ set at $734 \mathrm{ppm}$. The three GCMs were chosen (out of a set of 16 available in the AgMIP CMIP3 ensemble set (Hudson and Ruane, 2013)) to represent the uncertainty in projected rainfall changes at La Mercy, where sugarcane production is primarily rainfed. The average increase in annual rainfall for the subset of three chosen GCMs was 3\% above baseline, compared with $4 \%$ for the entire set. The second highest (14\% increase) and second lowest (11\% decrease) projections, along with the nearest to neutral projection (3\% increase), were selected. These corresponded with the MIROC3 2 MEDRES (K-1 model developers, 2004), MPI ECHAM5 (Jungclaus et al., 2006) and UKMO HADCM3 (Gordon et al., 2000) models. $\left[\mathrm{CO}_{2}\right]$ was assumed to be $734 \mathrm{ppm}$ for the future scenarios and $360 \mathrm{ppm}$ for the baseline scenario. Thirty crops were simulated for the baseline and future time periods (for each GCM) at each site and each harvest cycle (starting April and October). 


\subsubsection{Downscaling of future climate data}

Future weather datasets were generated using the Delta method (Wilby et al., 2004) whereby the observed (baseline) daily time series was adjusted to impose monthly temperature changes (difference between a GCM's future and baseline period) and percentage changes in rainfall, projected by each GCM. Although there may be more sophisticated methods for downscaling future weather data, the data produced by the Delta method are based on observations that contain local characteristics that are often lost in statistical climate data generation methods. It is also a relatively simple, easily understood method compared to more complicated approaches (for example the bias-corrected spatially disaggregated approach) for which the value added is not always clear. (Ruane et al., 2015)

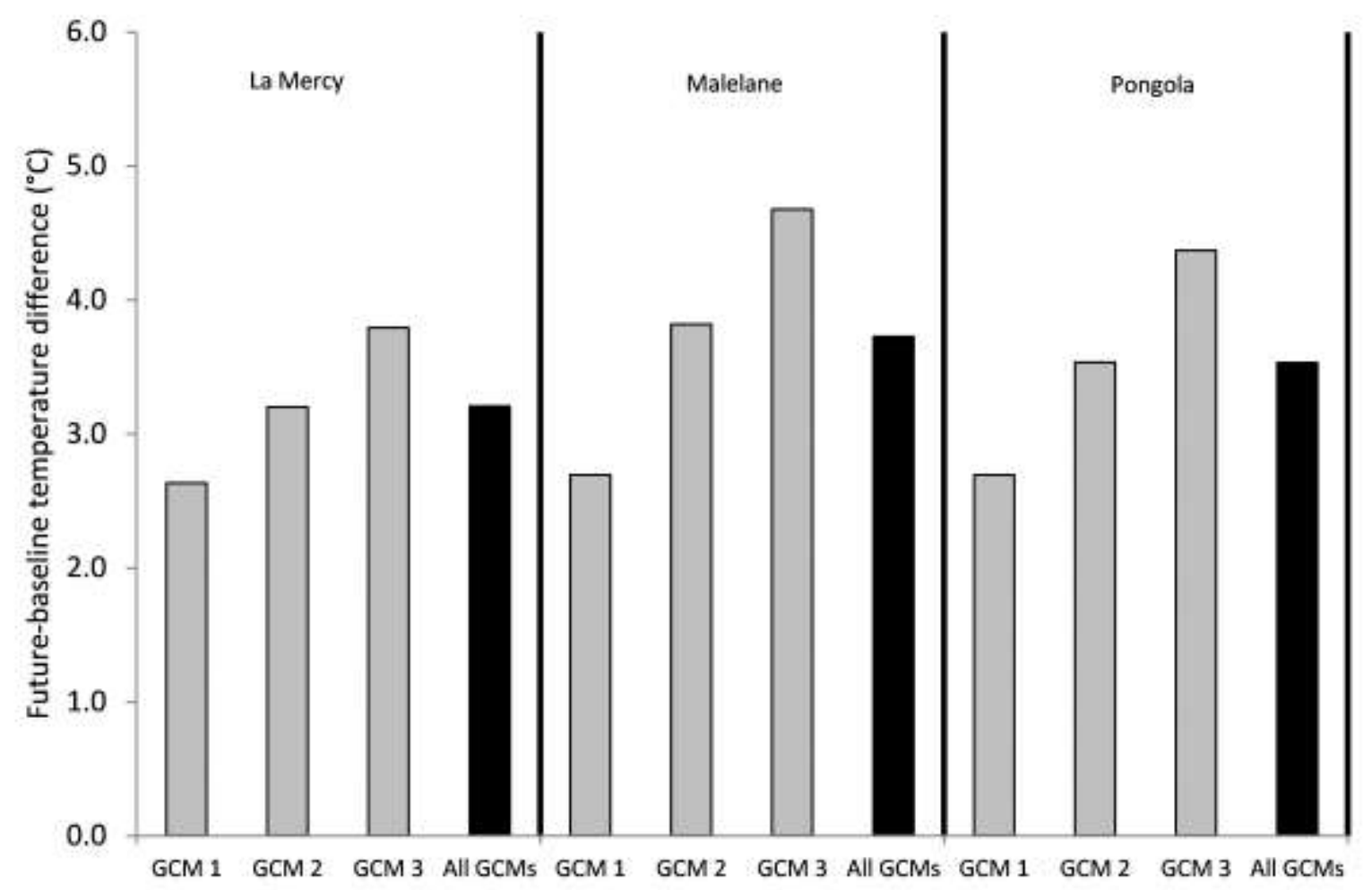

Figure 3. Future:baseline relative rainfall projected by each of the global circulation models (GCMs), for each site. GCMs 1, 2 and 3 refer to the MIROC3 2 MEDRES, MPI ECHAM5, UKMO HADCM3. The average of all GCMs is also shown for each site. 


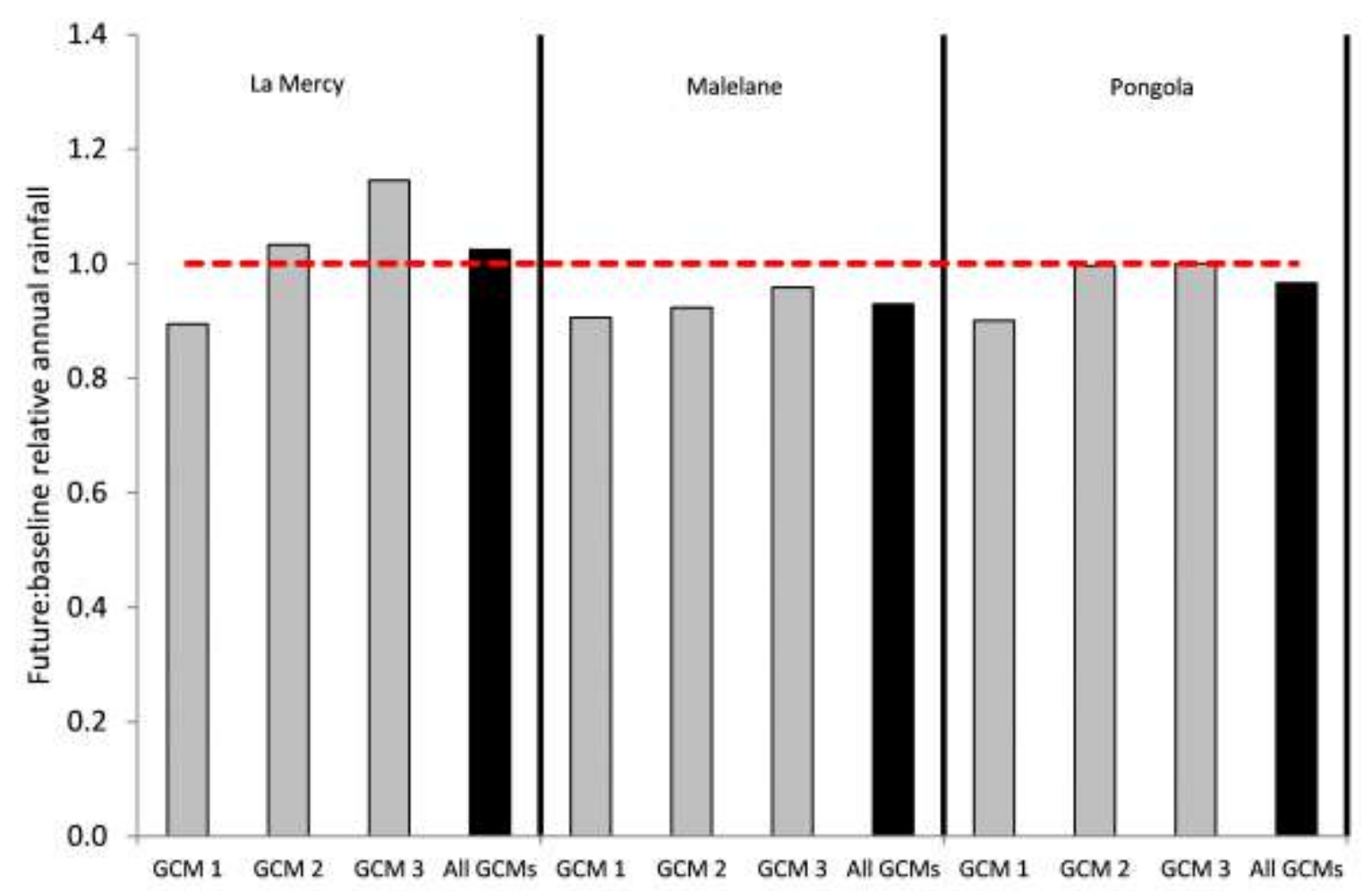

Figure 4. Future-baseline difference in air temperatures projected by each of the global circulation models (GCMs), for each site. GCMs 1, 2 and 3 refer to the MIROC3 2 MEDRES, MPI ECHAM5, UKMO HADCM3. The average of all GCMs is also shown for each site.

\subsubsection{Data processing and analysis}

Model outputs were aggregated and analysed using custom software implemented in the PHP v5 language and SQL, using a MySQL v5.1 database.

Water use efficiency (WUE, $\mathrm{t} / \mathrm{ha} / 100 \mathrm{~mm}$ (equivalent to $\left.\mathrm{kg} / \mathrm{m}^{3}\right)$ ) was calculated as the cane yield (t/ha) accrued per unit of water used by the crop $(E T, 100 \mathrm{~mm} / \mathrm{d})$. The water-use efficiency of irrigation water (IWUE, t/ha/100 mm (equivalent to $\left.\mathrm{kg} / \mathrm{m}^{3}\right)$ ) was defined as the increase in cane yield per unit irrigation applied $\left(V_{i r r}, 100 \mathrm{~mm}\right)$ : 


$$
I W U E=\frac{Y_{\text {Irrigated }}-Y_{\text {Rainfed }}}{V_{\text {irr }}}
$$

where $Y_{\text {irrigated }}(\mathrm{t} / \mathrm{ha})$ is simulated yield under irrigation, and $Y_{\text {rainfed }}(\mathrm{t} / \mathrm{ha})$ is simulated nonirrigated yield. Both rainfed and irrigated scenarios were simulated at each site in order to calculate these values.

Long-term means (LTM) of several variables per site were calculated by analysing simulation outputs either on a daily basis or at harvest, over 30 seasons for each time period. Long-term future variability per site was calculated as the standard deviation $(\sigma)$ of long-term average simulated values per GCM (i.e. the standard deviation of three values per site).

Inter-seasonal yield variability was calculated as $\sigma$ of yield values at harvest over 30 seasons for each site, time period and GCM (i.e. the standard deviation of 30 values per site, time period and GCM).

The coefficient of variation, expressed as a percentage (CV\%), was calculated as:

$$
C V \%=\frac{\sigma}{L T M} * 100
$$

\section{RESULTS}

\subsection{Weather data}

Under the projected future climate scenarios, rainfall increased on average by $2 \%$ at $\mathrm{La}$ Mercy, but decreased by $7 \%$ at Malelane and by $3 \%$ at Pongola. However, there was considerable variation in rainfall between GCM projections, particularly at La Mercy $(\mathrm{CV} \%=10.00)$ and to a lesser extent at Pongola $(\mathrm{CV} \%=4.77)$ and Malelane $(\mathrm{CV} \%=2.38)$ 
Future average temperatures increased by between $3.2{ }^{\circ} \mathrm{C}\left(\right.$ La Mercy) and $3.7^{\circ} \mathrm{C}$ (Malelane), with little variation between GCM projections (Table 1).

\subsection{Long-term mean impacts of climate change per site}

Table 3 summarises baseline and future simulated long term mean values. Figure 5 illustrates the impacts of future climate change, by expressing future simulated values relative to baseline simulated values. Both Table 3 and Figure 5 show variation (uncertainty) in future arising from differences in GCM projections.

Table 3. Simulated 30-year mean time to $80 \%$ canopy cover (fractional interception of photosyntheticallyactive radiation), time to the start of stalk growth, average daily canopy cover, cumulative seasonal evapotranspiration (ET), cumulative seasonal irrigation demand, cane and sucrose yield at harvest, and irrigation water use efficiency (IWUE) for the three sites studied, for baseline (1980-2010) and future (20702100) periods. Values in parentheses show standard deviation of GCM-estimated average values.

\begin{tabular}{|c|c|c|c|c|c|c|c|c|}
\hline \multirow[t]{2}{*}{ Variable } & \multicolumn{2}{|c|}{ La Mercy (rainfed) } & \multicolumn{2}{|c|}{ La Mercy (irrig.) } & \multicolumn{2}{|c|}{ Pongola } & \multicolumn{2}{|c|}{ Malelane } \\
\hline & Baseline & Future & Baseline & Future & Baseline & Future & Baseline & Future \\
\hline $\begin{array}{l}\text { Time to } 80 \% \\
\text { canopy cover } \\
\text { (d) }\end{array}$ & 178.5 & $\begin{array}{r}123.3 \\
(16.81)\end{array}$ & 116.1 & $\begin{array}{r}73.5 \\
(3.24)\end{array}$ & 107.5 & $\begin{array}{r}76.9 \\
(4.39)\end{array}$ & 97.8 & $\begin{array}{r}72.1 \\
(4.07)\end{array}$ \\
\hline $\begin{array}{l}\text { Time to start of } \\
\text { stalk growth (d) }\end{array}$ & 133.8 & $\begin{array}{r}98.7 \\
(5.04)\end{array}$ & 131.1 & $\begin{array}{r}96.4 \\
(4.34)\end{array}$ & 120.2 & $\begin{array}{r}92.8 \\
(5.53)\end{array}$ & 111.6 & $\begin{array}{r}80.0 \\
(5.36)\end{array}$ \\
\hline $\begin{array}{l}\text { Average canopy } \\
\text { cover }(\%)\end{array}$ & 67.2 & $\begin{array}{r}74.2 \\
(1.93)\end{array}$ & 75.0 & $\begin{array}{r}82.7 \\
(0.65)\end{array}$ & 76.8 & $\begin{array}{r}83.9 \\
(0.87)\end{array}$ & 78.9 & $\begin{array}{r}84.8 \\
(0.77)\end{array}$ \\
\hline $\begin{array}{l}\text { Intercepted } \\
\text { radiation } \\
\left(\mathrm{MJ} / \mathrm{m}^{2} / \mathrm{d}\right)\end{array}$ & 4202 & $\begin{array}{r}4583.2 \\
(117.37)\end{array}$ & 4666 & $\begin{array}{r}5088 \\
(38.03)\end{array}$ & 5032 & $\begin{array}{r}5438 \\
(53.98)\end{array}$ & 5392 & $\begin{array}{r}5751 \\
(50.27)\end{array}$ \\
\hline $\mathrm{ET}(\mathrm{mm})$ & 1141 & $\begin{array}{l}1258.8 \\
(21.48)\end{array}$ & 1180 & $\begin{array}{r}1309 \\
(18.74)\end{array}$ & 1407 & $\begin{array}{r}1555 \\
(27.38)\end{array}$ & 1527 & $\begin{array}{r}1687 \\
(34.30)\end{array}$ \\
\hline $\begin{array}{l}\text { Irrigation } \\
\text { demand (mm) }\end{array}$ & - & - & 531 & $\begin{array}{r}589 \\
(6.89)\end{array}$ & 802 & $\begin{array}{r}894 \\
(13.86)\end{array}$ & 971 & $\begin{array}{r}1082 \\
(31.59)\end{array}$ \\
\hline $\begin{array}{l}\text { Cane yield } \\
(\mathrm{t} / \mathrm{ha})\end{array}$ & 71.9 & $\begin{array}{r}82.9 \\
(5.75)\end{array}$ & 110 & $\begin{array}{r}125 \\
(1.94)\end{array}$ & 122 & $\begin{array}{r}137 \\
(2.54)\end{array}$ & 131 & $\begin{array}{r}145 \\
(2.64)\end{array}$ \\
\hline $\begin{array}{l}\text { Sucrose yield } \\
(\mathrm{t} / \mathrm{ha})\end{array}$ & 8.2 & $8.7(0.56)$ & 13.7 & $\begin{array}{r}13.6 \\
(0.18)\end{array}$ & 15.1 & $\begin{array}{r}13.7 \\
(0.40)\end{array}$ & 15.7 & $\begin{array}{r}13.3 \\
(0.63)\end{array}$ \\
\hline $\begin{array}{l}\text { WUE (t/ha/100 } \\
\mathrm{mm})\end{array}$ & 6.3 & $6.6(0.35)$ & 9.3 & $\begin{array}{r}9.6 \\
(0.01)\end{array}$ & 8.7 & $\begin{array}{r}8.8 \\
(0.01)\end{array}$ & 8.6 & $\begin{array}{r}8.6 \\
(0.02)\end{array}$ \\
\hline $\begin{array}{l}\text { IWUE (t/ha/ } \\
100 \mathrm{~mm})\end{array}$ & - & - & 7.2 & $\begin{array}{r}7.2 \\
(0.71) \\
\end{array}$ & 8.5 & $\begin{array}{r}8.2 \\
(0.39) \\
\end{array}$ & 9.0 & $\begin{array}{r}8.8 \\
(0.39) \\
\end{array}$ \\
\hline
\end{tabular}




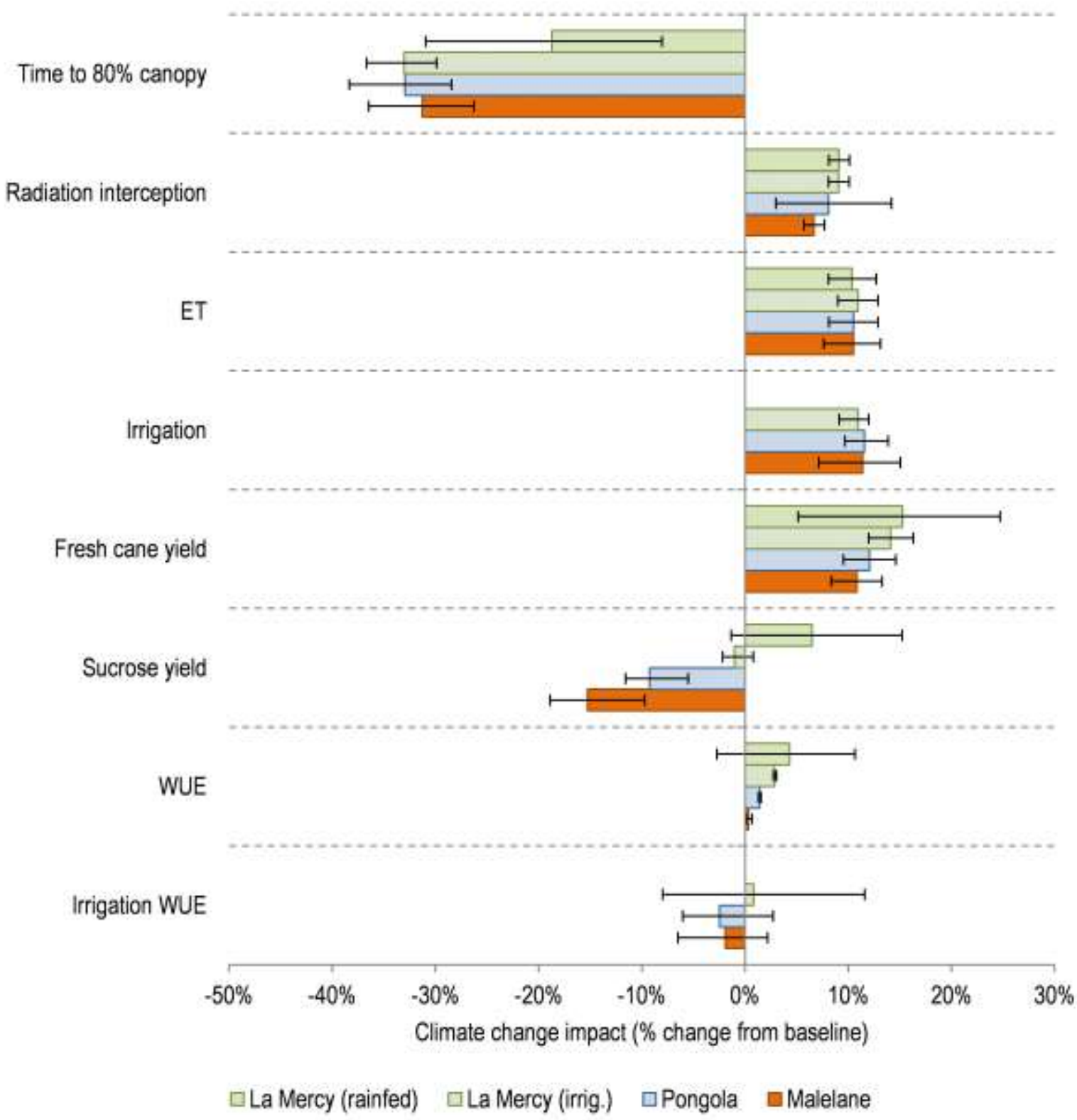

Figure 5. Average climate change impact (difference in long term mean values of each variable between future scenarios and the baseline scenario) predicted for the three sites. The error bars show the range (minimum to maximum) of impacts predicted by the three climate models.

Simulated cane yields increased under all future scenarios, at all sites; this is consistent with the findings of Knox et al. (2010), Marin et al. (2012), Schulze and Kunz (2010) and Singels et al. (2013). The relative increases were greatest at La Mercy (irrigated: $14 \%$; rainfed: $15 \%)$, and smallest at Malelane $(11 \%)$. Simulated yields were higher than the $47 \mathrm{t} / \mathrm{ha}$, 90 t/ha and 95 t/ha recent average yields reported respectively for the Maidstone (La Mercy 
rainfed), Pongola and Malelane mill supply areas (Singels et al., 2015; data for irrigated cane at La Mercy were not available), but show similar values relative to each other compared with the simulated yields shown in Table 3. The yield increases are ascribed to (1) greater interception of radiation (Figure 5) at all sites in future, arising from faster canopy development driven by higher air temperatures (especially at sites and times of the year when average temperatures increase in future above the base temperatures for expansive growth); and (2), increased gross photosynthesis rates (offset to some extent by increased maintenance respiration rates, however), also as a consequence of higher air temperatures. Results suggest that yield increases due to climate change are likely to be greater at currently lower-potential sites, and vice versa. This is explained by two factors. Firstly, at lower-potential sites, a unit increase in temperature results in a relatively larger increase in thermal time $\left(T T,{ }^{\circ} \mathrm{C} d\right)$ accumulation, by virtue of average baseline temperatures being closer to the threshold base temperatures; secondly, at higher temperatures and biomass yields, the burden of maintenance respiration as a proportion of gross photosynthesis increases; higher-potential sites are generally warmer and have greater biomass yields, so a unit increase in temperature results in a smaller relative increase in net photosynthesis - and hence yield - at currently higher-potential sites. Variation in simulated cane yields was relatively low at all irrigated sites, suggesting high levels of agreement between the GCMs' predictions of temperature.

Sucrose yields increased under rainfed production at La Mercy, but decreased under irrigated production at all three sites. This is in contrast with the findings of Knox et al. (2010) for Swaziland (which is geographically situated between Malelane and Pongola), who reported that sucrose yields might increase by $15 \%$. Their (single GCM) projections were for a nearer time period (2050s), with smaller temperature increases; also, a different version of the DSSAT-Canegro model (v3.1) was used, in which radiation use efficiency and maintenance respiration are not linked to temperature, and sucrose accumulation follows a more empirical 
approach than in v4.5. Generally, the currently warmer the site, the greater the decrease in sucrose yields (Figure 5). Sucrose content (a measure of cane quality) decreased at all sites. Impacts on sucrose yield and content are driven by (1) increased simulated maintenance respiration rates leading to a reduction in assimilate supply, and (2) increased simulated demand of assimilate for structural growth (see Fig 20.6 in Singels, 2014), both caused by increased temperatures, and (3) relatively little response in assimilate supply (photosynthesis rate) to temperature. The last two effects have been well documented in field and controlled environment studies (Hatch and Glasziou, 1962; Ebrahim et al., 1998; Lingle, 1999; InmanBamber et al., 2010; Grof et al., 2010; Singels et al., 2010). These responses were particularly evident for high biomass crops approaching an early season harvest (April) when temperatures are relatively high. The effect was much less pronounced in October crops when temperatures during the period leading up to harvest are lower than that of April crops.

Irrigation demands increased consistently across all sites (because of increased ET, a consequence of increased radiation interception, higher biomass, increased temperatures, and decreased annual rainfall at Malelane and Pongola). The increases were not as large as the 20-22\% increase for the mid-century scenario reported by Knox et al. (2010) for Swaziland. This discrepancy is attributed to the different GCM and time period used - a similar increase in ET was reported $(11 \%)$, but with a larger decrease $(5 \%)$ in future annual rainfall. The increases are, however, similar to the findings of Schulze and Kunz (2010), who indicate irrigation demand increases at La Mercy, Pongola and Malelane of 10-20\%, 0-10\%, and 10$20 \%$ respectively. The value of irrigation water in terms of yield (as captured by $I W U E$, Figure 5) decreased in future at Pongola and Malelane. The IWUE results depend on the future increase in yield compared with the future increase in irrigation demand, but are also partly influenced by the increased WUE - increased radiation interception (less nonproductive soil surface evaporation) and reduced stomatal conductance (from elevated $\left[\mathrm{CO}_{2}\right]$ ) 
led to more effective use of rain water. Despite relatively higher variability in rainfall projections compared with those for temperature, GCM variation in irrigation demand between the irrigated sites was low. Irrigation supplies and the capacity of water delivery infrastructure will need to increase in future at Pongola and Malelane.

\subsection{Inter-seasonal variation in yields}

Season-to-season variation in simulated cane yields decreased in future scenarios compared with the baseline (Figure 6). Variation in simulated yields is driven primarily by variability

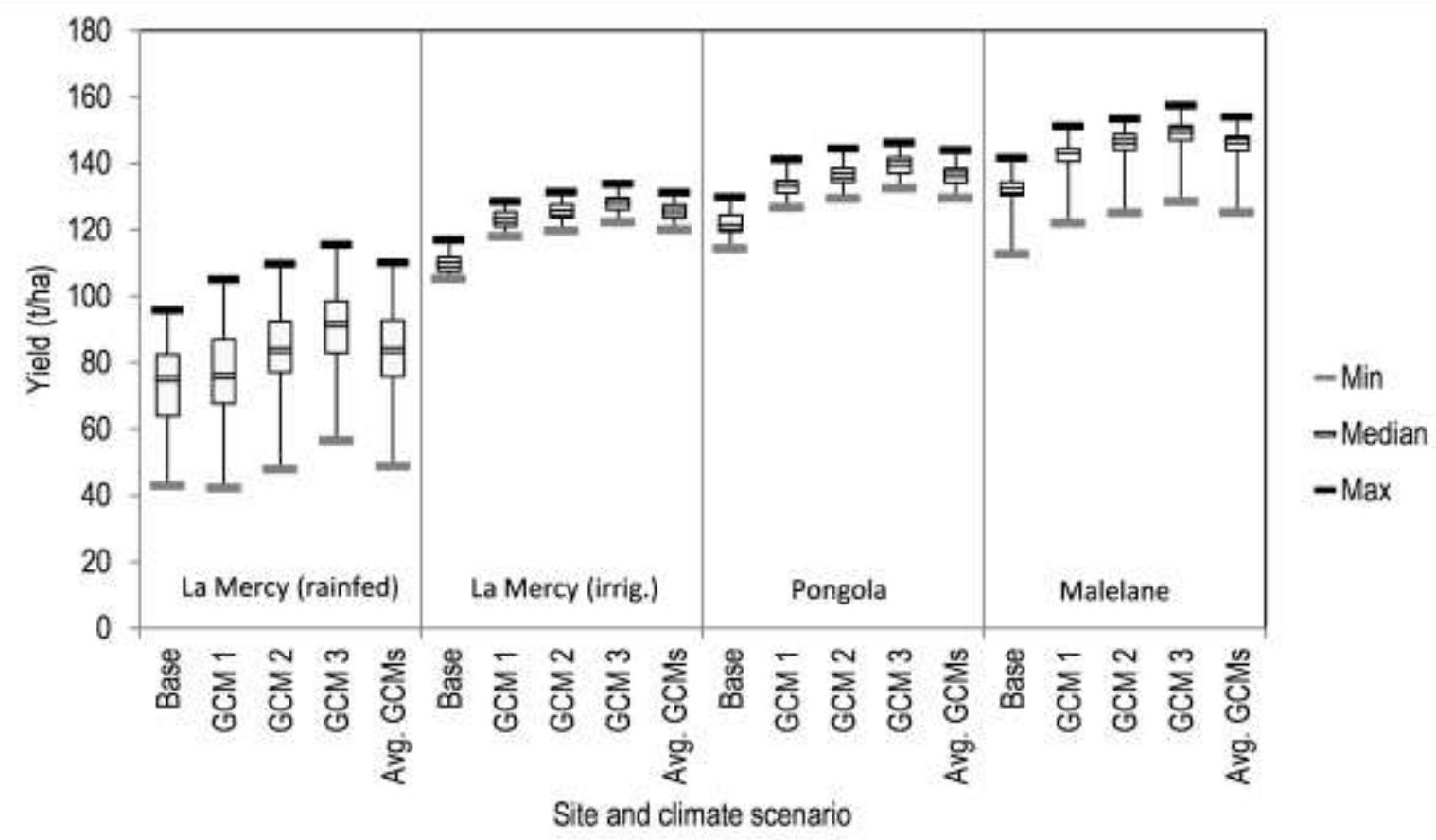

Figure 6. Box and whisker plot showing simulated sugarcane yields for rainfed and irrigated production at La Mercy, and irrigated production at Malelane and Pongola, for the historical baseline scenario ('Base'), each of three GCM-projected scenarios ('1' = MIROC3 2 MEDRES, '2' = MPI ECHAM5, '3' = UKMO HADCM3) and the average of the three GCM scenarios ('Avg. GCMs'). The boxes show values between the first and third quartiles. The average of April and October cropping cycle yields is shown.

in seasonal temperature and solar radiation under fully-irrigated production, and to a relatively much greater extent also by rainfall amount and distribution under rainfed 
production. This is evidenced by the greater variability in simulated yields at La Mercy under rainfed production, compared with the irrigated sites. The coefficient of variation of simulated cane yields decreased from $19.5 \%$ to $16.8 \%$ under rainfed production at La Mercy, $2.7 \%$ to $2.3 \%$ under irrigated production at La Mercy, $3.2 \%$ to $2.7 \%$ at Pongola, and $4.3 \%$ to $3.8 \%$ at Malelane.

Results presented in Figure 5 and Table 3 suggest that irrigated cane yields are expected to increase at all three sites (by $14.1 \%$ at La Mercy, $12.1 \%$ at Pongola and $10.8 \%$ at Malelane), due to increased interception of radiation from accelerated canopy development (as a result of higher future temperatures), as well as increased radiation use efficiency simulated for higher temperatures. Evapotranspiration increased by $10.6 \%$ due to increased canopy cover and evaporative demand, despite the inhibiting effect on transpiration of elevated $\left[\mathrm{CO}_{2}\right]$. As the crop canopies developed faster in future scenarios, relatively less soil moisture was lost to non-productive soil surface evaporation. This, combined with the elevated $\left[\mathrm{CO}_{2}\right]$ effect on transpiration, improved overall WUE. The increase in ET meant that irrigation requirements increased by about $11 \%$ at all sites. IWUE increased by $0.9 \%$ at La Mercy and decreased $2.5 \%$ and $2.0 \%$ respectively at Pongola and Malelane.

Simulated inter-seasonal variation in irrigated cane yields (as indicated by CV\%) decreased at all sites, with the largest decrease (14\%) at La Mercy. This confirms that (low) temperature is currently a limiting factor at La Mercy, and to a lesser extent at the other sites. These results imply that future sugarcane production might become more consistent from season to season, which should be beneficial.

\subsection{Crop cycle variation}

Figure 7 shows a comparison of baseline and future average fractional interception of photosynthetically-active radiation (canopy cover) by days after crop start at La Mercy, and 
reveals much-accelerated canopy development in future, particularly for April crops that develop their canopy in the cooler autumn months. Figure 8 shows the interaction of crop cycle and climate change on yield at each site.

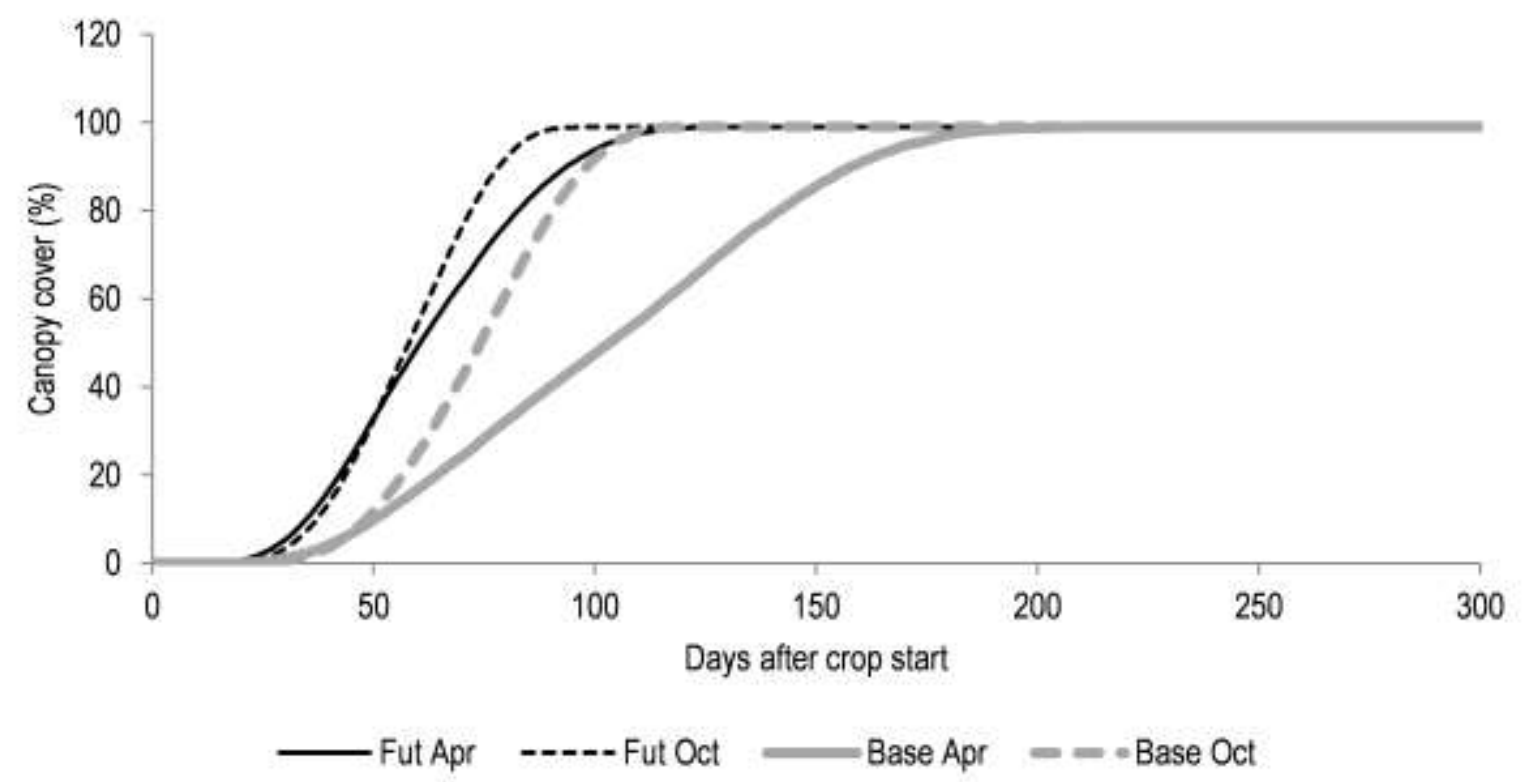

Figure 7. Simulated canopy cover (fractional interception of photosynthetically-active radiation) for irrigated production at La Mercy. April ('Apr') and October ('Oct') cycles, for the historical baseline scenario ('Base'), and the average of three GCM scenarios ('Fut'), are shown.

Substantial increases in annual thermal time accumulation rate, and therefore canopy development rate, resulted at sites and times of the year when future climate change was projected to increase average temperatures from below to above the base temperatures for expansive growth, and where baseline temperatures were relatively low. At the currently coolest site, La Mercy, future irrigated canopy development for April crops was substantially accelerated compared with the baseline period (Figure 7).

Radiation interception increased for all future crops, with relatively larger increases in April crops $(+10.6 \%)$ than October crops $(+6.2 \%)$. This translated into greater future yield 


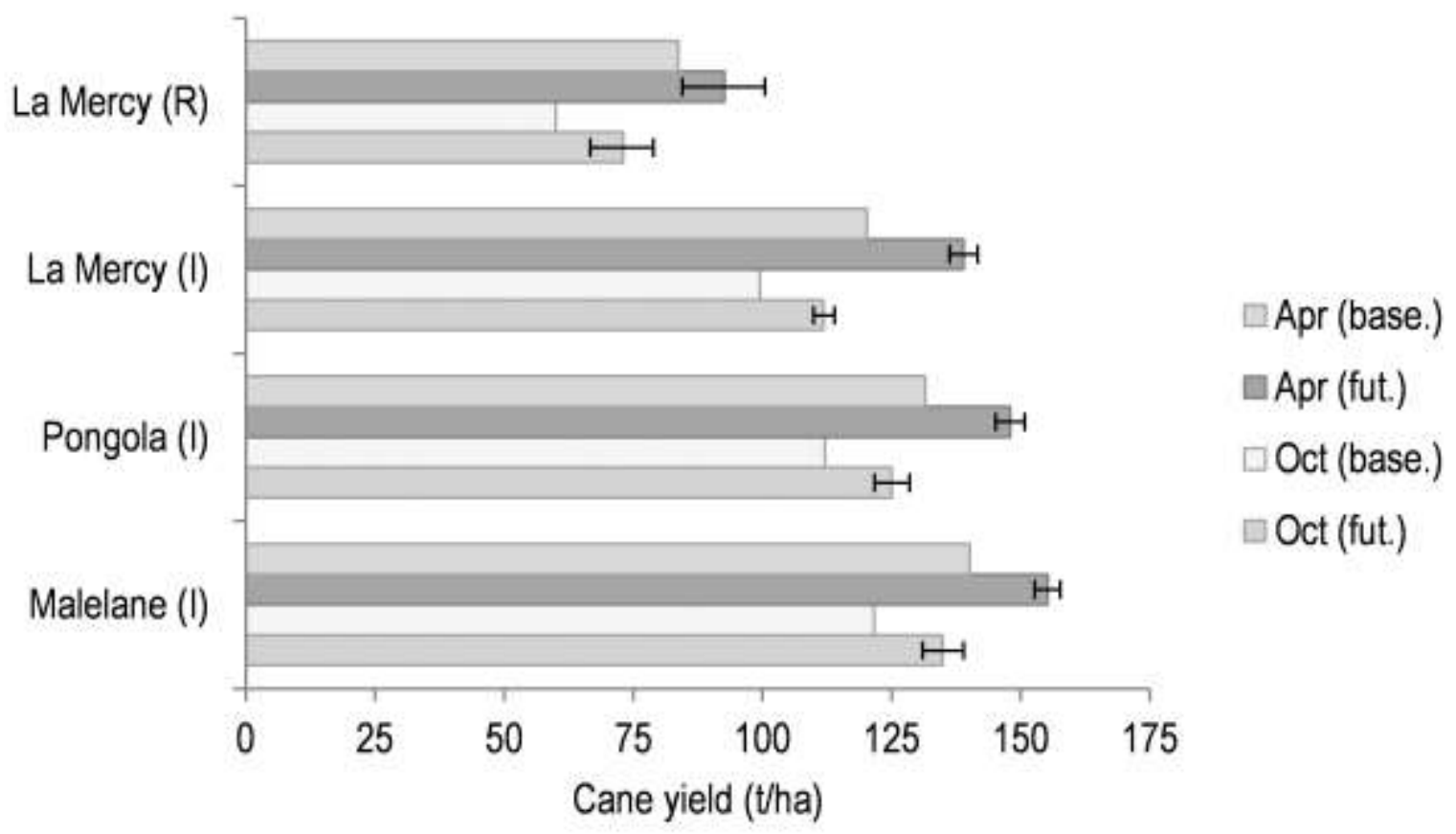

Figure 8. Impact of projected climate change on simulated average seasonal cane yield per crop, at each site. Averages of 30 crops each, for April ('Apr') and October ('Oct') growth cycles, baseline ('base.') and future ('fut.') time periods. The error bars indicate the maximum and minimum values (averaged over 30 seasons) with variation from GCMs. 'R' indicates rainfed crops while ' $I$ ' indicates irrigated crops.

increases relative to baseline for April crops compared with October crops (Figure 8), for irrigated production at all three sites. The rainfed treatment at La Mercy showed relatively higher yields for October crops, however, due to higher levels of water stress in the future April crop. 


\section{DISCUSSION}

\subsection{Possible adaptation measures}

This work has revealed insights that could lead to climate change adaptations and farming system changes which have the potential to increase yields under climate changed future conditions, and/or mitigate against cost increases associated with climate change.

The faster canopy development noted in these results implies a shorter period in which weeds can effectively grow. Weeds are also likely to develop faster in future, but spraying operation costs tend to be linked to the number of spraying operations rather than the level of weed infestation, so weed control costs might decrease in future.

Increased demand for irrigation water in future could be countered by changing to more efficient irrigation technologies (such as sub-surface drip) and precision scheduling of irrigation, consistent with the recommendations made by Knox et al. (2010), Park et al. (2010), Schulze and Kunz (2010) and Chandiposha (2013). Retention of crop residues has been identified by Park et al. (2010) as a possible climate change adaptation to improve water management in sugarcane. Crop residue blankets have the potential to reduce non-productive soil surface evaporation losses: van den Berg and Jones (2006) reported increased soil moisture availability of $100 \mathrm{~mm}$ per season for rainfed crops, while Olivier and Singels (2014) recorded reductions in crop water use in irrigated sugarcane of up to $150 \mathrm{~mm}$. This might, however, be a less effective farming system change in future with the shorter partial canopy period and/or if sub-surface drip irrigation is used. Retention of crop residues could also become a more desirable management practice in future in areas where the current temperature climate is too cold to gain any yield advantage from doing so. 
The increases in thermal time accumulation rates noted across all sites in the future scenarios suggest that there may be some opportunity to reduce age at harvest (consistent with the findings of Schulze and Kunz, 2010), although this is countered against reduced radiation interception. Decreasing net photosynthesis (due to increasing respiration) as the crop ages suggests that there might be an optimal thermal time age at harvest at which annualised yields are maximised. Higher yields in future might increase the incidence and severity of lodging, and reducing harvest age might also combat this, by ensuring that cane crops are cut before severe lodging sets in (typically around 130 t/ha cane yield, van Heerden (2014)), which might reduce associated yield losses and additional harvesting costs. Given the likelihood of increased lodging in future, there may be a prerogative for sugarcane breeders to focus on lodging resistance as a desirable trait.

Results suggest that cane quality (sucrose content) will be negatively affected by climate change, especially at the beginning and end of the conventional harvesting periods when hot weather is likely to prevail. Chemical ripening will be an important practice to counter this impact, and methodologies may have to be adjusted for optimal efficiency for future climates. Changes to the duration and timing of the harvesting season could also be explored to minimise negative impacts of climate change (as suggested by Park, 2008).

\subsection{Methodology issues}

The AgMIP integrated assessment framework provides a methodology that proved to be robust and useful. The climate-crop model 'interface' is accessible and requires minimal input other than baseline weather data. Some very valuable insights have been gleaned from this study: (1) indicative impacts of climate change on yield in irrigated sugarcane; (2) indicative impacts of climate change on likely future irrigation demand; and (3) the identification of possible model weaknesses. The AgMIP protocol allows for including 
additional GCMs (and GCMs from the more recent CMIP5, Taylor et. al., 2013), time periods, emissions scenarios and more sophisticated downscaling techniques.

The study by Singels et al. (2013) highlighted possible shortcomings in the methodology that apply here as well. Future assessments may find greater adherence to historical conditions by utilising the agricultural-impacts oriented version of the MERRA dataset for gap-filling (AgMERRA; Ruane et al., 2014). The Delta climate change projection downscaling technique is relatively unsophisticated. Results here indicate that shifts in mean temperature are the driving force behind sugarcane yield changes. GCM projections of temperature change are far more consistent than precipitation change projections, suggesting it is sufficient to analyse a small ensemble such as that assembled here. A weakness of the climate data used was the assumption of no changes in the number of rain-days per month, solar radiation and relative humidity in future scenarios - variables that are important in determining crop water status and irrigation requirements. Future assessments are therefore advised to explore the use of AgMIP's mean-and-variability scenario approaches, which adjust the number of rain-days and the distribution of extreme temperatures in addition to mean changes (Ruane et al., 2015).

Low levels of variation in the predictions of cane yield and irrigation demand were noted in this study. This is probably due to relatively high levels of agreement between the GCMs with respect to temperature projections, which in turn had a more dominant effect on yield and irrigation demand than rainfall. It is tentatively suggested that in regions where GCMs show agreement on temperature and annual rainfall projections are within -10 to $+10 \%$ of the baseline, small GCM ensembles may be sufficient for climate change impact assessment studies in irrigated sugarcane. 


\subsection{Model limitations}

The study also demonstrated some limitations of the DSSAT-Canegro model. These include the calculation of effective temperature, simulated response of photosynthesis and respiration to temperature, and the disconnect between biomass accumulation and expansive growth.

Effective temperature drives phenological and growth processes in the model and is a linear function of daily mean temperature above the specified base temperature. There is no cap on effective temperature. As a result, the crop develops and grows faster with increasing temperature, even when temperatures are so high that the plant is unlikely to function effectively. For most current climates this algorithm produced reasonable results because temperatures seldom exceeded optimal (about 30 to $35^{\circ} \mathrm{C}$, van Dillewijn, 1952; Liu et al., 1998; Ebrahim et al., 1998; Keating et al., 1999; Bonnet, 2014) of the relevant plant processes. For the projected future climates studied here, average daily temperatures remained below well below $30{ }^{\circ} \mathrm{C}$ (Table 1), although the average number of days per annum with daily average temperatures above $30^{\circ} \mathrm{C}$ increased to 9, 33 and 71 for La Mercy, Pongola and Malelane respectively. We conclude that crop responses, particularly canopy development rate, to increased temperatures simulated in this study may be slightly over estimated and that the model needs refinement to mimic temperature responses more accurately for scenarios where temperatures often exceed optima. The APSIM-Sugar (Keating et al., 1999) model makes use of minimum (base), optimal and maximum cardinal temperatures for the calculation of effective temperature (thermal time). It is suggested that a similar approach is implemented in the DSSAT-Canegro model.

Simulated radiation use efficiency increases at a decreasing rate with daily mean temperature, while simulated maintenance respiration rate increases exponentially with increasing daily mean temperature, again without a cap on the response (see Singels et al., 2005). The daily 
amount of assimilate required by maintenance respiration is also proportional to the amount of dry biomass. This means that when the crop becomes very large, most assimilate may be consumed by respiration, leaving little or no assimilate for growth and sucrose storage. This point is reached sooner when temperatures are higher. It is suggested that the respiration algorithm be revised to reflect a decrease in maintenance respiration rate above an optimal temperature, and to account for the different maintenance requirements of different plant materials (dead and live leaf, stalk and root fibre, and stalk sugars) (Amthor, 2000). This should result in lower respiration rates in big crops or at very high temperatures, and could lift the current simulated cane yield cap and increase simulated sucrose yields.

In DSSAT-Canegro the simulation of canopy expansion is driven primarily by effective temperature (and water status), and is disconnected from the biomass accumulation algorithm. In reality, canopy expansion requires the allocation of assimilate produced by photosynthesis. The very rapid canopy expansion simulated under future high temperature will only be realised if it can be supported by a concomitant increase in carbon assimilate rate. This is unlikely because the primary driver of simulated carbon assimilation is solar radiation, which is not expected to increase to the same extent as temperature. It is suggested that the canopy expansion algorithm be linked to the biomass accumulation algorithm (see Jones et al., 2011) to ensure biological integrity.

\section{CONCLUSIONS}

This simulation study suggests that canopy development of future crops is likely to be far more rapid than current crops, due to elevated temperatures, especially for autumn crops. The quicker canopy development led to increased interception of radiation and increased 
transpiration. Increased evapotranspiration (and decreased rainfall in some cases), caused increases in irrigation demand of about $11 \%$ at all sites. Cane yields are expected to increase by between 11 and 14\%, provided that increased irrigation requirements can be met. Sucrose yields decreased because of the additional consumption of photo-assimilate by increased rates of maintenance respiration and greater partitioning of biomass to structural growth rather than sucrose.

Inter-seasonal variations in climate change responses were also minimal, for the same reason. These outcomes suggest that small GCM ensembles may be sufficient for climate change impact assessments in irrigated sugarcane. Crop response in canopy development and yield formation to climate change differed markedly between the two crop cycles investigated, highlighting the need to include this aspect in climate change impact studies for sugarcane.

Results point to several agronomic implications that require actions to minimize negative impacts and exploit positive impacts. These include reduced weeding costs due to shortened periods of partial canopy, a need for improved efficiency of irrigation to counter increased demands, and adjustments to ripening and harvest practices to counter decreased cane quality and optimize productivity.

Although the Delta climate data downscaling method is considered robust, accurate and easily-understood, future weather data generated using the Delta downscaling method has the possible weakness that it does not change the future number of rain-days per month. Additionally, in this study, future solar radiation and relative humidity were assumed not to change from the baseline. The impacts of these simplifications ought to be explored in future work. Shortcomings of the DSSAT-Canegro model include the calculation of effective temperature, simulated response of photosynthesis and respiration to temperature, and the disconnect between simulated biomass accumulation and expansive growth. Proposed 
refinements to the methodology should improve the reliability of predicted climate change impacts on sugarcane yield.

\section{ACKNOWLEDGEMENTS}

This study was funded by the South African Sugarcane Research Institute (SASRI). Many thanks to Phillemon Sithole and Shenay Harisunker at SASRI for their assistance in preparing baseline weather datasets, and to the AgMIP community for developing the methodologies used.

\section{REFERENCES}

Allen, L.H.Jr., Vu, J.C.V., Anderson, J.C., and Ray, J.D. (2011). Impact of elevated carbon dioxide and temperature on growth and sugar yield of the C4 sugarcane. Curr. Top Plant Biol. 12: 171-178

Amthor, J.S. (2000). The McCree-de Wit-Penning de Vries-Thornley respiration paradigms: 30 Years Later. Ann. Bot. 86: 1-20.

Bonnet, G.D. (2014). Developmental stages. In: Physiology, biochemistry and functional biology of sugarcane. (Ed: P.H. Moore and F. C. Botha). 541-571. World in Agriculture Series. Wiley-Blackwell. ISBN $978-1-118-77138-9$

Chandiposha, M. (2013). Potential impact of climate change in sugarcane and mitigation strategies in Zimbabwe. Afr. J. Agric. Res. 8 (23): 2814-2818, doi: 10.5897/AJAR2013.7083.

De Souza, A.P., Gaspar, M., da Silva, E.A., Ulian, E.C., Waclawovsky, A.J., Nishiyama M.Y.Jr., dos Santos, R.V., Teixeira, M.M., Souza, G.M., and Buckeridge, M.S. (2008). Elevated CO2 increases photosynthesis, biomass and productivity, and modifies gene expression in sugarcane. Plant Cell Environ. 31: $1116-1127$

Ebrahim, M.K.H., Vogg, G., Osman, M.N.E.H., and Komor, E. (1998). Photosynthetic performance and adaptation of sugarcane at suboptimal temperatures. J. Plant Physiol.: 153: 587-592 
Easterling, W.E. (2011). Guidelines for Adapting Agriculture to Climate Change. In: Hillel, D., and

Rosenzweig, C. (Eds). Handbook of climate change and Agroecosystems: Impacts, Adaptation and Mitigation. Imperial College Press, London, United Kingdom. ISBN-10 1-84816-655-9.

Gordon, C., Cooper, C., Senior, C.A., Banks, H.T., Gregory, J.M., Johns, T.C., Mitchell, J.F.B., and Wood, R.A. (2000). The simulation of SST, sea ice extents and ocean heat transports in a version of the Hadley Centre coupled model without flux adjustments. Clim. Dynam., 16: 147-168.

Grof, C.P.L., Campbell, J. A., Kravchuk, O., Lambrides, C.J., and Albertson, P.L. (2010). Temperature effect on carbon partitioning in two commercial cultivars of sugarcane. Funct. Plant Biol. 37: 334-341

Hudson, N., and Ruane A.C. (2013). Guide for Running AgMIP Climate Scenario Generation Tools with R. AgMIP. Available online: http://www.agmip.org/wp-content/uploads/2013/10/Guide-for-Running-AgMIPClimate-Scenario-Generation-with-R-v2.3.pdf (accessed March 2014).

Inman-Bamber, N.G. (1995). Climate and water as constraints to production in the South African sugar industry. Proc. S. Afr. Sug. Technol. Ass. 69: 55-59.

Inman-Bamber, N.G. (1991). A growth model for sugar-cane based on a simple carbon balance and the CERES-Maize water balance. S. Afr. J. Plant Soil 8(2): 93-99.

Inman-Bamber, N.G., Bonnett, G.D., Spillman, M.F., Hewitt, M.L., and Jingsheng Xu (2009). Source-sink differences in genotypes and water regimes influencing sucrose accumulation in sugarcane stalks. Crop Pasture Sci. 60: 316-327

Inman-Bamber, N.G., Bonnett, G.D., Spillman, M.F., Hewitt, M.L., and Glassop, D. (2010). Sucrose accumulation in sugarcane is influenced by temperature and genotype through the carbon source-sink balance. Crop Pasture Sci. 61: 111-121.

Jones, J.W., Hoogenboom, G., Porter, C.H., Boote, K.J., Batchelor, W.D., Hunt, L.A., Wilkens, P.W., Singh, U., Gijsman, A.J., and Ritchie, J.T. (2003). The DSSAT cropping system model. Eur. J. Agronomy 18:235-265.

Jones, M.R. (2013). Incorporating the Canegro sugarcane model into the DSSAT v4 Cropping System Model framework. Unpublished M.Sc. thesis, University of KwaZulu-Natal, Pietermaritzburg.

Jones, M.R., Singels, A. and Inman-Bamber, N.G. (2011). Simulating source and sink control of structural growth and development and sugar accumulation in sugarcane. Proc. S. Afr. Sug. Technol. Ass. 84: 157-163 
Jungclaus, J. H., Botzet, M., Haak, H., Marotzke, J., Mikolajewicz, U., Roeckner, E., Keenlyside, N., Latif, M., Luo, J. J., Giorgetta, M. A., Brasseur, G. P., Roeckner, E., and Marotzke, J. (2006): Ocean circulation and tropical variability in the AOGCM ECHAM5/MPI-OM. J. Climate. 19: 3952-3972

K-1 model developers (2004): K-1 coupled model (MIROC) description, K-1 technical report, 1, H. Hasumi and S. Emori (eds.), Center for Climate System Research, University of Tokyo, 34pp.

Keating, B.A., Robertson, M.J., Muchow, R.C., and Huth, N.I. (1999). Modelling sugarcane production systems. I: Description and validation of the APSIM sugarcane module. Field Crops Res. 61: 253-271.

Knox, J. W., Rodríguez Díaz, J. A., Nixon, D. J., and Mkhwanazi, M. (2010). A preliminary assessment of climate change impacts on sugarcane in Swaziland. Agr. Syst., 103(2): 63-72.

Lingle, S.E. (1999). Sugar metabolism during growth and development in sugarcane Internodes. Crop Sci. 39: 480-486.

Liu, D.L., Kingston, G. and Bull, T.A. (1998) A new technique for determining the thermal parameters of phenological development in sugarcane including suboptimal and supra-optimum temperature regimes. Agric For. Meteor. 90: 119-139

Marin, F. R., Jones, J. W., Singels, A., Royce, F., Assad, E. D., Pellegrino, G. Q., and Justino, F. (2012). Climate change impacts on sugarcane attainable yield in southern Brazil. Clim. Chang., 1-13.

Meehl, G.A., Covey, C., Delworth, T., Latif, M., McAvaney, B., Mitchell, J.F.B., Stouffer, R. J. and Taylor, K. E. (2007). The WCRP CMIP3 multimodel dataset: a new era in climate change research. Bull. Amer. Meteor. Soc., 88(9): 1383-1394

Nakićenović, N., Alcamo, J., Davis, G., De Vries, B., Fenhann, J., Gaffin, S., Gregory, K., Grübler, A., Jung, T., and Kram, T. (2000). IPCC special report on emissions scenarios (SRES). Cambridge University Press, Cambridge, United Kingdom.

Nkomo, S., and van der Zaag, P. (2004). Equitable water allocation in a heavily committed international catchment area: the case of the Komati catchment. Phys. Chem. Earth 29: 1309-1317.

Olivier F.C., and Singels, A. (2014). Increasing water use efficiency of irrigated sugarcane in South Africa through by better agronomic practices. Field Crops Res. (under review). 
Park, S.E., Crimp, S., Inman-Bamber, N.G., and Everingham, Y.L. (2010). Sugarcane. In: Stokes, C., Howden, M. (Eds) Adapting agriculture to climate change: preparing Australian agriculture, forestry and fisheries for the future. CSIRO Publishing, Collingwood, Australia, pp 85-99.

Park, S.E. (2008). A review of climate change impact and adaptation assessments on the Australian sugarcane industry. Proc. Aust. Sugar Cane Technol. 30:1-9.

Rienecker, M.M., Suarez, M.J., Gelaro, R., Todling, R., Bacmeister, J., Liu, E., Bosilovich, M.G., Schubert, S.D., Takacs, L., Kim, G.-K., Bloom, S., Chen, J., Collins, D., Conaty, A., da Silva, A., et al. (2011). MERRA: NASA's Modern-Era Retrospective Analysis for Research and Applications. J. Climate, 24: 3624-3648, doi:10.1175/JCLI-D-11-00015.1

Rosenzweig, C., Jones, J.W., Hatfield, J., Antle, J., Ruane, A., Boote, K., et al. (2013). Guide for Regional Integrated Assessments: Handbook of Methods and Procedures Version 5.0. New York. http://www.agmip.org/refbase/uploads/cynthiarosenzweig/2013/170_CynthiaRosenzweig2013.pdf (accessed 14 October 2014)

Rosenzweig, C., Jones, J.W., Hatfield, J.L., Ruane, A.C., Boote, K.J., Thorburn, P., Antle, J.M., Nelson, G.C., Porter, C., Janssen, S., Asseng, S., Basso, B., Ewert, F., Wallach, D., Baigorria, G., and Winter, J.M. (2013) The Agricultural Model Intercomparison and Improvement Project (AgMIP): Protocols and pilot studies. Agr. Forest Meteorol. 170: 166-182.

Ruane, A.C., Winter, J.M., McDermid, S.P., and Hudson, N.I. (2015). AgMIP Climate Datasets and Scenarios for Integrated Assessment. In Handbook of Climate Change and Agroecosystems. The Agricultural Model Intercomparison and Improvement Project (AgMIP). C. Rosenzweig, and D. Hillel, Eds., ICP Series on Climate Change Impacts, Adaptation, and Mitigation Vol 3: 45-48. Imperial College Press.

Ruane, A.C., Goldberg, R., and Chryssanthacopoulos, J. (2014). Climate forcing datasets for agricultural modeling: Merged products for gap-filling and historical climate series estimation. Agr. Forest Meteorol., in press. doi:10.1016/j.agrformet.2014.09.016

Schulze, R.E. and Kunz, R.P. (2010). Climate Change and Sugarcane Production Using the Smith Model. In: Schulze, R.E. 2010. Climate Change and the South African Sugarcane Sector: A 2010 Perspective. University of KwaZulu-Natal, Pietermaritzburg Campus, School of Bioresources Engineering and Environmental Hydrology, ACRUcons Report 61. Chapter 12, 73 - 81. 
Singels A, Leslie GW, McFarlane SA, Miles N, Gabriel A and Nicholson R. (2015). Review of South African sugarcane production in the 2014/2015 season from an agricultural perspective. Proc. Int. Soc. Sugar Cane Technol, 89:(CD-ROM)

Singels, A. (2014). Crop Models. In: Physiology, biochemistry and functional biology of sugarcane. (Ed: P.H. Moore and F. C. Botha). 541-571. World in Agriculture Series. Wiley-Blackwell. ISBN 978-1-118-77138-9 Singels A., Jones, M.R., Marin, F., Ruane, A.C., and Thorburn, P. (2013). Predicting climate change impacts on sugarcane production at sites in Australia, Brazil and South Africa using the Canegro model. Proc. Int. Soc. Sugar Cane Technol., 87:(CD-ROM).

Singels, A. and Inman-Bamber, N.G. (2011) Modelling genetic and environmental control of biomass partitioning at plant and phytomer level of sugarcane grown in controlled environments. Crop Pasture Sci. 62:66-81.

Singels, A., Jones, M.R., Porter, C.H., Smit, M., Kingston, G., Marin, F., Chinorumba S., Jintrawet., A., Suguitani, C., van den Berg, M., and Saville, G. (2010). The DSSAT4.5 Canegro model: A useful decision support tool for research and management of sugarcane production. Proc. Int. Soc. Sugar Cane Technol., 84: (CD-ROM).

Singels, A., Jones, M.R., and van den Berg, M. (2008). DSSAT v4.5 Canegro Sugarcane Plant Module: Scientific documentation. SASRI, Mount Edgecombe, South Africa. pp 34.

Singels, A., Donaldson, R.A., and Smit, M.A. (2005). Improving biomass production and partitioning in sugarcane: theory and practice. Field Crops Res. 92: 291-303.

Singels, A., and Bezuidenhout, C.N. (2002). A new method of simulating dry matter partitioning in the Canegro sugarcane model. Field Crops Res. 78: 151-164.

Stokes, C.J., and Inman-Bamber, N.G. (2014). Climate ready sugarcane: Traits for adaptation to high CO2 levels. Final Report for Sugar Research Australia Project CPI018. CSIRO, Townsville, Australia.

Taylor, K.E., Stouffer, R. J., and Meehl, G. A. (2012). An overview of CMIP5 and the experiment design. Bulletin of the American Meteorological Society, 93 (4): 485-498, doi:http://dx.doi.org/10.1175/BAMS-D-1100094.1

van den Berg, M., and Jones, M.R. (2006). Modelling trash management and its impacts: model performance. Proc. S. Afr. Sugar Technol. Ass. 80: 159-162. 
van Heerden, P.D.R. Personal communication, November 2014.

van Dillewijn, C. (1952). Botany of Sugarcane. Waltham, Mass, USA.

Vu, J.C.V., Allen, L.H.Jr., and Gesch, R.W. (2006). Up-regulation of photosynthesis and sucrose metabolism enzymes in young expanding leaves of sugarcane under elevated growth CO2. Plant Science 171: 123-131.

Vu, J.C.V., and Allen, L. H., Jr. (2009) Stem juice production of the C4 sugarcane (Saccharum officinarum) is enhanced by growth at double-ambient CO2 and high temperature. J. Plant Physiol. 166:1141-1151.

Wilby, R.L., Charles, S. P., Zorita, E., Timbal, B., Whetton, P., and Mearns, L.O. (2004). Guidelines for use of climate scenarios developed from statistical downscaling methods. IPCC task group on data and scenario support for impact and climate analysis (TGICA).

World Meterological Organisation (2007). The role of climatological normals in a changing climate.

WCDMP-No. 61 WMO-TD No. 1377. www.wmo.int/datastat/documents/WCDMPNo61_1.pdf (last accessed 14 October 2014). 